by adopting the tivick braid solution.

ii) ihe too sield nerformance of a trained magnet is altimatery linited by the short sanple charactiaristics of tine braid at the print at aighest local ragnetic tiold, $B$ m... Considering the nxample of the coil in

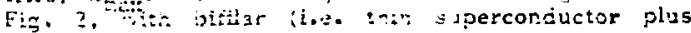
ceacer iurasl instodel ot the inis braid one ards a

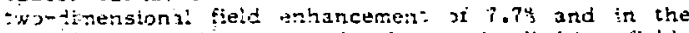
ands ily. lin the propused solution the liniting field, $B^{\prime}$-.., xccurs in the munotilar tarns and the respective

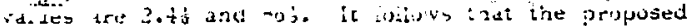
solution nas its shout sample pertornance improved by about + t.

iii) The field in the braid of the upper blocks near the pole is" more or less constant with radius and parallel to the braid, whereas in the lower blocks the field diminishes along the radius and is prinarily perpendicular to the braid. The nonotilar turns at the location of the limiting field Blax are in a ronuniform field. In :act, the ifield here changes by about $30 \%$ over the braid width which sugzests that the local enthaloy reserve and siability ggainst quenching is enhanced. Counteracting this gain is the anisotropy of the sritica! Gureent in the braid, which is about 194 leswer for 3 perpendicular to the braid i:.e. the isual test condition). It is conceivahie that ine jagnet rerains stable in the current-sinarind state, but pperation in this mode ts not recommengec.

iv) Incigental to this solution, but nevertheless of considerable pracical importance, is the possibility of dsing preinsulated oraid thereby eliminating the need tor hanfwrapping of mutitular tuens, and making posibie presinding insuiation tests of the iull length at conducior.

\section{CONDLCTOR DEVELOP:IENT}

The :apgraded coil cortiguration requires, in addition to the stanciard braid. a conductor essentially of trice caicknesi, that is 1.47 instead of $0.71 \mathrm{~mm}$. It is intunded to produce the new conducterin the form of I 54 strand braid with the nominal cross section of $16.5 \% 1.5 \mathrm{~mm}$ including insulation. A comparison of the oraic paimetrers is given in rable 1.

I he dewlogment dit thek toraid as been undertaken 2 inllaboration with mastry (AItC), lurra: llill, iew lersevi and irst test jieces have been produced and

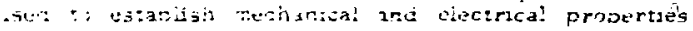

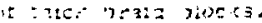

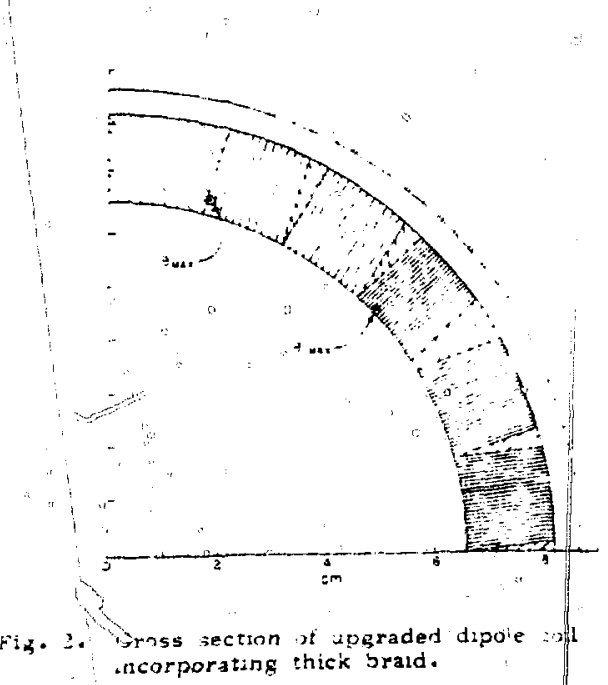

Table 1. Braid Paramecers

\begin{tabular}{|c|c|c|c|}
\hline$\Rightarrow$ & Standard & Thick Braid & unit \\
\hline aij dimensions & $15.3 \times 0.7$ & $16.3 \times 1.5$ & $\min ^{2}$ \\
\hline To." of strands & $\begin{array}{r}97 \\
0.10\end{array}$ & $\begin{array}{r}59 \\
057\end{array}$ & 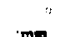 \\
\hline Hire liameter & 0.30 & 0.57 & m \\
\hline Silatent di meEer & 9 & 17 & \\
\hline Vo. 11 aments/wize & $\begin{array}{l}500 \\
1.5\end{array}$ & $\begin{array}{l}500 \\
1.5\end{array}$ & $\because 4$ \\
\hline 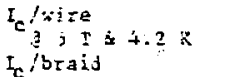 & 55 & 200 & $A$ \\
\hline $\begin{array}{l}\text { aj Is } 4.2 \mathrm{k} \\
\text { Transposition }\end{array}$ & -.5 & 12 & $\mathrm{kA}$ \\
\hline $\begin{array}{l}\text { length } \\
\text { Interstrand }\end{array}$ & 30 & 40 & $\cos$ \\
\hline $\begin{array}{l}\text { resistance* } \\
\text { glastic modulus }\end{array}$ & $\begin{array}{r}5 \\
25\end{array}$ & $\begin{array}{r}0.3 \\
14\end{array}$ & $\begin{array}{l}-\mu \overline{\mathbf{z}} \\
\mathrm{GP} \mathbf{a}\end{array}$ \\
\hline
\end{tabular}

* Fille 1 with staybrite (Sn.tg) but without high resistance heat treatment.

Parenthetically it should be remarked that it is, of course, possible to increase the matrix/SC ratio some what in order to reauce the additional cost incurred from using nore superconductor. This would retain the winding simplifications, but may come the expense of the full stability gain. oln the case pf quadrupoles such a mocified ticick braid would certainiv bo acceptable.

\section{COIL DESIGN CONSIOERA TIUNS}

Whereas, it can be expected that the thick braid (i.ll lead to an improved training and peak field performance, it is necessary to in "estigate other aspects "entering the coll design, such as quench propagation, nagnetization, $B$-dot effects, insulation, ends, joint of thict thin braid, etc.

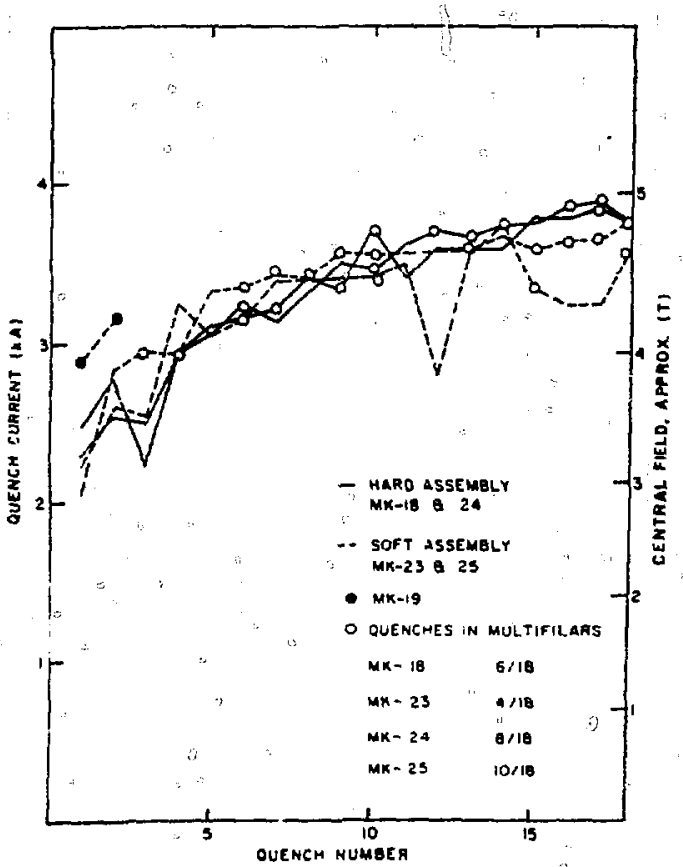

Fig. 3. Irauning curves of recent tl.st ipoles. Open curcles repcisent quenches $0^{\circ}$. rinating in zultifia- turns. 
Ot primary concern here is azimuthal quench propagation velocity which, to a large extent, determines magnet self-protection during a quench. The maximum tersperature reached in the coil during a ciuench is related :o the $i l^{2} \mathrm{dt}$ integral and depends inversely on a.:inuzai juench veiocity. An upper init on this incearal is about $3.5 \mathrm{kA}$ sec $\vdots n$ the ronofilar turns iol. which in the desizn according to Fig. 1 is the isticzl region. The tolerance $t o$ heating of $a$ thick iraid is larger by 1 factor of 1 whereas the turn-tofurn aziouinal quench propagation time has been sitimated $\{7\}$ to increase only by a factor 2.8. These scaling arguments indicate that the nonofilar turns remain the critical region in the thick braid design of Fig. 2. Experiments on propagation through thick meta! wedges indicated that their delay is equivilent to 3 to \& monofilar turns $|8|$. Results of more detailed calculations 191 of maximum temperatures in the sroposed design are shown in Fig. 4, suggesting that the ragnet will be self-protecting during a quench provirled that the nominal monofilar turn-to-turn transit :ime is less than about $2 \mathrm{msec}$. With proper fabrication technigues this requirement can be satisfied. It has been observed that azimuthal quench propagation depends strongly (up to factor 10 variation) on

- the presence of helium witnin the cwinding. i.e. the coil porosity, and

- jood contact between iurns which is helped by pressure during the coil winding process and assembly.

Eddy currents induced in the superconducting braid while the magnet current is being ramped can produce substantial field distortions and power losses. Tie total power dissipation per unit length of the dipole is ziven by 110$\}$

$$
P=\frac{\mathrm{n}^{2} \mathrm{w}^{2} \mathrm{2} y}{360} \frac{\dot{\mathrm{B}}^{2}}{\mathrm{R}}
$$

where $n, *, 2$ are number of wires, width and transposition ength of braid respectively, $R$ the interstrand ressstance. N the total number of turns, and $B$ the ramp rate. Induced field harmonics are minimized by an exponential ramp rate, with $B / B=5.4 \times 10^{-3} \mathrm{sec}^{-1}$ during the $8 \mathrm{~min}$ ramp time from 0.37 to $5 \mathrm{~T}$. Under these conditions, the standard braid exribits a maximum power

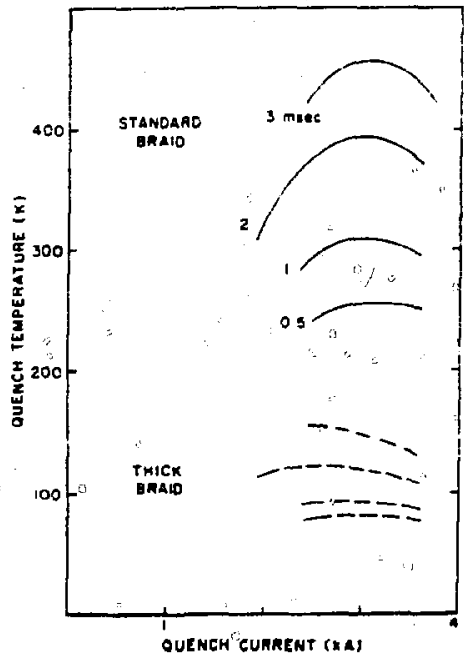

Fig. 4 . Calculated maximum temperatureduring a quench which starts at the pole. Parameser is the nominal turnoto-turn transit time at $3.1 \mathrm{kA}$. loss of $60 \mathrm{~W} / \mathrm{m}$. which is unacceptable. Heat treatment and nechanical cracicing of braic filler is expected to produce the desired nigh resistance braid with an order of magnitude increased interstrand resistance [11]. This treatment would also have to be applied to the taick braid. The incremental pover loss tue is the zoplication of tinick braid can be "estimated to be

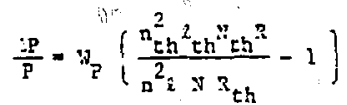

where the index "th" refers to the thick braid values and she geometrical peighting factor is given by

$$
W_{P}=\int_{0}^{\pi / 2} \cos ^{3} \theta \mathrm{de} / \int_{0}^{\pi / 2} \cos ^{3} \mathrm{~s} d \theta=0.08
$$

with $D=\operatorname{arc} \cos \left(\mathrm{N}_{t h} / \mathrm{N}\right)$. Using the numbers of Table 1 one finds a 158 increase of the loss. Stmilar expressions, but with changed weighting actors apply to the induced rield harmonic coefficients. We conclude that reducing the interstrand resistance is :he ortvailing concern, whereas the ise ot tinick braid of itself causes only minimal changes.

Induced SC magnetization currents in the illaments are the cause of power losses and rield changes at injection. An upper-limit estimate of the increase in the iield coefficients is given by

$$
\left.\frac{\Delta b_{n}}{b_{n}}=w_{D}=\frac{d^{3} \operatorname{th}^{n} t h^{I} t h}{d^{3} n I}-1\right)
$$

where $d, n, 1$ are the filament diameter, total number of filaments, and the critical current of the obraid respectively. In the worst case, the dipole term, $W_{0}=0.35$ neglecting the azimuthal field variation in the coil. One finds that the dipole error due to magnetization increases by less (presumably by much less) than a factor 3, which would seem acceptable. Note that magnetization ef iects could be reduced by going to more filaments of smaller diameter.

The upgraded coll configuration is substitutional for tie standard coil and few changes in fabrication technique are expected. The thick braid will be insulatec in the same way as the standard braid with b-staje epuxy-impregrated tiberglass tape $50 \mathrm{ym}$ thick. Consideration is yiven to acding a single $25 \mu \mathrm{m}$ kapton layer if better insulation is judged necessáry. The necessary overlap joint between thick and standard traid will be located at one end, and made by routine practice. The higher stiffness of the "nhick braid requires additional tooling to form the ends, but no serious complication is expected.

\section{TEST MAGNETS}

In order to verify the increased stability arguments, two tull-size test magnets ( $\mathrm{MK}-19$ and 20 ) were built in which the inert spacers were replaced by superconducting turns. SC spacers were used in earLer short magnets $|12|$ and more recently in $\mathrm{Nb}_{3} \mathrm{Sn}$ magnets $|13|$ to increase the current stability of the turns near the pole. The winding scheme for the test magnets is shown in Fig- 1 (with $\mathrm{MK}-19$ being insignificantly differenf) and the important parameters are isted in Table 2. Both magnets were soft asiembled with UK-20 directly comparable to $M K-23$ and 25 . MK-19 in contrast, was assembled like $\mathrm{MK}-5$ (the best performing dipole) with stress relieved fiberglass bands. masking tape between coil and banda, and the bore tube supporting the coil. MK-19 was wound with natural ends, MK-20 with end spacers. 
Table 2 Full Bize Test Yagnets

\begin{tabular}{|c|c|c|c|}
\hline & $9 \mathrm{~K}-19$ & $1 \mathrm{~K}-20$ & Inic \\
\hline 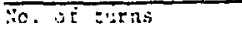 & 192 & $: 32$ & \\
\hline Trsnsfer Eunction & $1 .+23$ & $1 .+15$ & $T ; B=1$ \\
\hline 3ilit in $h=$ & $\begin{array}{l}-25 \\
-\quad 1\end{array}$ & - 15 & 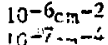 \\
\hline 宓 & $-\quad 39$ & $-\quad 44$ & $10-8=-6$ \\
\hline 3 & -1.1 & 13.34 & $10-9=-18$ \\
\hline Ed:הas & IE.7 & +1.9 & 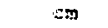 \\
\hline$I_{c} \div 5: \ldots 2 n$ & $+.25 \div \div .35$ & $4 ! 15 \leq+.55$ & $\mathrm{kA}$ \\
\hline$\therefore$ la:t: $: 401: 185$ & $:)$ & 13 & $G ?_{3}$ \\
\hline PEבic: & $\rightarrow$ & 3 & $: 19 a$ \\
\hline
\end{tabular}

The particular arrangement witi superconducting inert tarns is subject to substantial eddy current ifects iurias ramping and tie najnets are effectively dc nagnets jnit. The maximum induced current $i_{s}$, in steady state rimping. estimated to be

$$
I_{\text {edd }}=\frac{\pi^{2}}{9} \frac{\partial}{0}\left(\frac{B}{I}\right) T \dot{I}
$$

with $r$ the time constant, $w$ the braid width and i il ine transier function. The observed time constant is on the order ot one hour resulting in 800 A induced current in the araic at the ramo rate of $0.01 \mathrm{~A} / \mathrm{sec}$. Thr induced currents art additive to the transport current and the critical current is easily exceeded duriry ramping. Interchanging active and spacer turns would have resulted in a subtraction of the eddy' curant and a substantial improvement of performance. The :Te constant depends quadratically on the spacer turn iengtr: cutting the spacer length would practicaly eliminate the eddy current eifects.

The effectiveness of the superconducting turns in sippressing training quenches depends on the time required to switch the current locally from the active into the superconductirg spacer turn (the current diffusivity is about $10^{3} \mathrm{~m}^{2} / \mathrm{sec}$ ). it has been estimated that a minum propagating zone can be bypassed within a few silliseconds, which nay well be marginal at top iijld. At lower iields quench recovery has been soserved.

The :est naznet $16-1^{9}$ ynderwent about to low field quencnes di ijst ramp rates intal the eddy current efiect vas correctiv jiagnused. $4 k-i$, nad then its tirs:

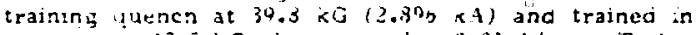
sne itep to $+2 . j \mathrm{k} G$ vinen ramped at $10.01 \mathrm{i} / \mathrm{sec}$. Iraining was stopped due to nagnet damage caused by a Cilure $0:$ the quenca protection circuit. Testing ot $M \mathrm{~K}-20$ is torthcoming.

A noninductive simulation coll, $50 \mathrm{~cm}$ ionz, was wound with thick braso in order to test traintng behavior and quenci elocitres. Vo traning quenches were observer at $j . j \mathrm{I}$ up to the nagnet design current of $t$ kA. $|8|$.

\section{CONCLUSION}

It is." in our opinion. justified to discount the eddy current quenches observed on $\mathrm{MK}-19$." Under this assumption, its periormance would seem to be superior to all other standard dipoles iested recently (Fig. 3). However, it is noc possible, without further work, to attribute it to the presence of superconducting spacer turns rather than some other aspects of the magnets, such as :he particular asembly tachnique applied to $M K-19$. The results are in any case sufficiently encouraging to pursue the thick braid solution with vigor.

Thick braid has been delivered by industry to ehis laboratory is quantities acequate for construction of 3 dipole and several zuadrupoles. In view of its greater simplicity, the construction of a iull size quadridole, $1.0 \mathrm{~m}$ long, is uncer consideration (Fiz. 5). Ths srmary surcose of this test maznet is io ain inaciton axperiencr and to verity the

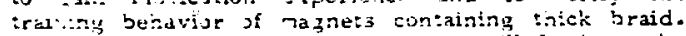
it : : expecied that this first step will land is the corsiruction at iull-size itpole ragnets.

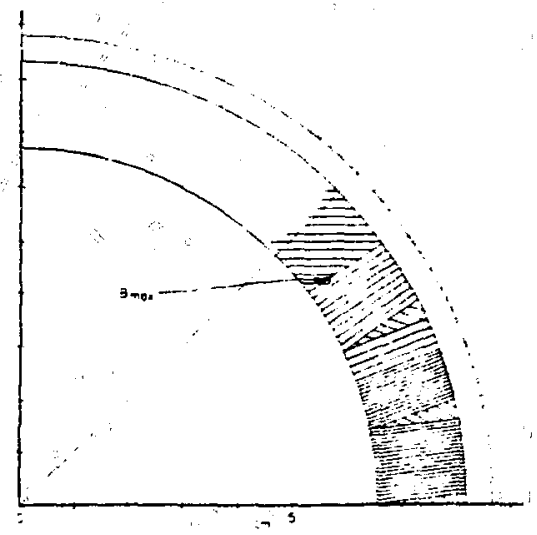

Fig. 5, Cross section ot thick braid quadrupole.

\section{ACENOWLEDGMENTS}

The authors would like to thank the Wazset $T_{t}$ Eacility under Dr. R. Engelmann :or testing the ma net. Lluminating discussiuns with Ors. W.B. Samps and $S . L$. Wipt and nelpfil contributions by $\mathrm{Dr} A$. Stevens are gratefully acknowledgec.

\section{REFERENCES}

(1) H. Hahn, IËEE Trans. MAG-17. 702 (1981).

[ 2] E.J. Bleser. "Cunstruction of Superconducting Sagnets at Brjokhaven National Laborator:" these sroceedings.

13 : H. Hann, "A semilexible Cul with Graded Ourrent bensity for ISABELLE vagrets", to be published in Proc. Superconducting Magnet Norkshop. Broóthaven (10BU)

$1+1$ P.F. Dahl and H. Hahn, 1EEE Trans. MAG-17. 168 (1981).

(j) S.L. Wipt, "Stability and Degradation of Superconducting Current-Carrying Devices", Los Aiamos Scientific Report, LA7275 (unplablished 1978).

[ b] Marber and W.B. Sampson, IEEE Trans. MAG-17. 77 (1)81).

| 7 | J.D. Jackson, "Theory of Transverse Quench Propagation". ISABELLE Tecnnical Note 234 (unpiblished 1980 ).

(3) N.B. Sampson, private communcation (1081). I) A.J. Stevens. private communication (1981).

(10) E.D. Courant. "Eddy Currents in Superconducting Brad", lJABELLE Technical Note 168 (unpubblished 1980).

[11] T. Lihman. "Netadurgical Characterization of NbTi Braid", ISABELLE Technical Note No. 274 (unpubished 1980).

[12] W.B. Sampson. P.F. Danl. A.D. Melnturff. G.H. Morzan. Proc. tih Inters. Conf, Magnet Technology, Brookhaven 1972 (NTIS Springtield, VA) P. 752 .

(13) W.B. Sampson, S. Kiss, K.E. Robins, A.D. VeInturf, IEEE Trans. MAG-15, 117 (1979). 
7t: Intem. Conf. on 'agnet zechnology, Karlsruhe, Germany, Yarch 30-Aprt1 3, 1981.

BNL 29307

UPGRADED COIL CONFIGLRATION FOR ISABELLE IIAGNETS

H. Hahn. P.F. Dainl, J.E. Kaugerts, and A.'S. Prodeil

thstrzct - Acievenen: of the desiza fieio of $\partial$ I in the ISABEl. Lf jipole nagnets is turning out to be Tore ardunus than expected and several averiues of improvement are being pursued. Une possibility for improving training and peak ile?d periormance is discussed in :his paper. It nas been recognized that the inert spacers with their adjacent ictive turns in the cosine majnet windings can be replaced by a double rackness oraij operating at approximately hal:-current Eensity in 46 of the 140 turns. Since the high-fiedd region securs in the low current density turns near the oles, zerformance improvement can be expected. It has open verified that the proposed coil configuration jatisties toe tie!t requirements and teasis thereof are given. Sesults from an experimental nagnet in xrach superconducting space: turns are used to: simulate haif-current density windings are presented. Constriction sf tiack sraid coils is being pianneis and se stainj ot these magnets is roviesej.

\section{IXT?ODELIM}

+ proton-proton coilicing jeam acility iS A3ELLE is under construction ai 3roukharen Nationai Laboratory il) The tyn rings are each almosi $t$ in in circumter-

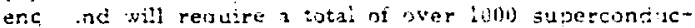
in jagnets. Tne dicoles are 4-3.4 1 iong, nave 3

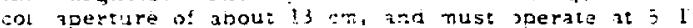

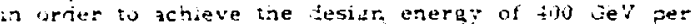
ring. The major reciluments for the nagkets, in addiiion to poerational tield strenyth, can be summarized under acceptable tritring, startic and aynamic field aua.ity, reproducibiity from magnet to majnet, ranp isses. selt-protection during guenching, assence of eiectrical shorts, and sanuiac:jublity winin a limit buaget. The development of superconducting dipuies is turning out to be mors arduous inan expected. Experance wi:h deveiopmental nagnets has shown that the soove requirements nave been $n \leq$ : individually on particular naynets; howerer, tney have not as yet been achieved consistentiy in seres of nagnets. The nost visible difficulty in the present drooie magne: is the iarge number of training quenches required to reach Jesign tie.d, aithough all nagnets seem "t.) reach shortsample currert if trainec iong enough. I substantial Ku.J Jrouram has jeen hauntea :o deviso in adeouate understanding of the imitations anc is inprove the periornance of the ISABELLE magnets [?!. In spite of cunsiderade progress which has been nade so far it seens scvisatie is investigate solutions xhich depart from tae original desizn concepts of in this paper a proposal tor improving training and peak iield performance of the jimites involving unly sunstrtiotional changes is iscusiea.

\section{LPGRADEJ COIL CONEIGIRATION}

The col configurations tor lipole and quadrionte raznets are single laver Tuitible siock approxinations to cosine current instrbutions, wolz ind tron a high aspert ratio nun-keystoned araided conductor. The azimuthal current density vanation is obtained by an approoriate distribution $f$ briled inert spacer turns. The criss section of recant test hajets 15

Slanuscrept received Warch 39, iog,

ivork pertormed under the luspices ol she C.s. Department ot Enerzy.

The authors are Nith Srookhaven Vational Labor

atory, L'pton, Ve's York 11973 show: in rad t. The col is sinrinx-fitted into a cold iron core which is $75 s e m b$ is i from insolit laminacions heid in a heavy wall stainless steel tube.

it has been recognized that ine spacers with their adjacent active turns can be repiaced by a double inickness oraic uperating at mperoximately half the current density $|3|$. Since the high-iield region cours in the low zurrent densiy turns near the poles, a periornance improvement can be expected.

Graced conductor has been used :n the past to reduce cost by sperating at aporoximatelv constant produet $\rightarrow$ i curtent densit: simes lucal fieic. The aroposed scheme on the contrary has the jojuctive of pack:ng the naximum possible amidat $\lambda$ superconductor into a given cross section. 1:1 jur particuiar case, about a 29"3 adition of VbTi an the entire coil is a-

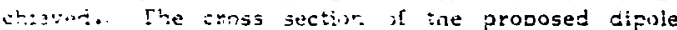
soi :s: shown !n Fig. 2. The confizuration luses a : ve-jock to tarn per juaciant jolution win the upper :wo blueks contaning the 23 double trickness turns $[4]$. lacorporating a single thick metal vedge betweon jlock 3 and $f$ jattsiies the field shape requirenenis. It nust be emohasized that the overall con "ametry remans uncianged and thus all improvenents in assembling and sinink fitting the coils dereiosed fir the standard coil will be appicable. inve the arguinents are developed in this paper for ite dipole cast, the apply aiso to the auadrupole although rodifications are here less pressing.

The sse of thick braid is expected to improve the pertormance in several ways:

i) I he two blociss operating at half-current density will have an increased stability margin against quenching, thus reducing the number sf trainitg quenches required. The enthalpy reserve of a thick braid is almust an order of magnitude larger than for the thin braid at equal current and field $|j|$. Vaking olauslb!e assumptions on the quench inducing disturbances. ane can expect that no iraining quencies will occur in the thick braid region. In order to obtain an esimate of the likely reduction in trasning, the quench orizin has been located in four recent magnets (MK-13, $23,1,25)$. From Fig. 3 it can be seen that in the average $+11 \%$ (7 of the first 18) guenches origunate in multitlar turns and presumably could be eliminated

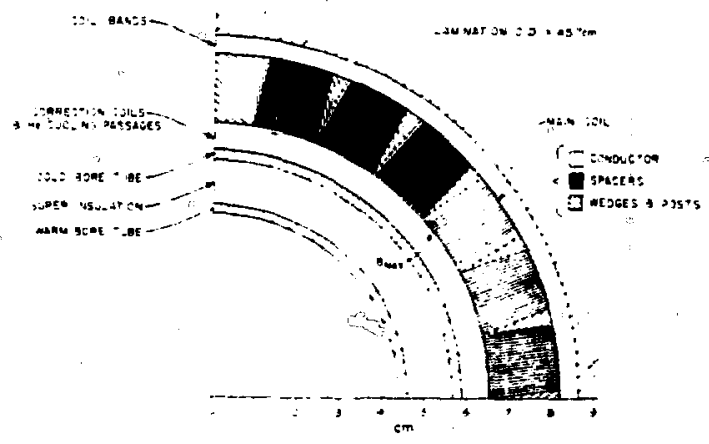

Fig. 1. Eross section of R\&D dipoles. 
by zdopting :ne thick pra:d solution.

i1) ine top tiela rectornance it a trained magnet is Litimitel: inted o: tie short siteple charactoristics d) :he brid it se puat it highest local magnetic

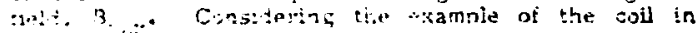

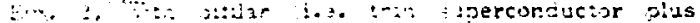

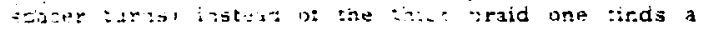

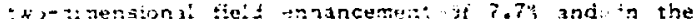

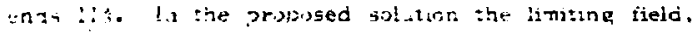
$3^{\prime} \ldots$, jecurs $n$ the nuntilar t:ms and the respective

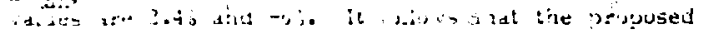
sidution nas lts inw iample serer.r tence impruved by about the

ii) The theld $: n$ the braid of tre zoper bloc's near the aole iz nore or less constant witn radius and parailel to the braid, whereas in the lower blocks the field diminsthes along the radius int is primarily perpendicular to the braid. l'he annotilar turns at the weation s: the limiting field $y$.axare is anunitorm tield. In :act, the thelo here changes by about 308 over iac braid wiath which gliggests that the iocal enthalay reserve and siability against querconing is erhancea. Counteracting this gatn is the anisotropy of the Eritica! iurreat in the oraid, winich "is about $10 \%$ uwer :or 3 perpensicular to the beaid ise. the isual iest conditionl. It is sonceivabic : $2 \pi$ t ine aaznet rerayns stable in the current-sharn.s state, bui operatjur. in tais mocie : 3 not recommences.

iv) Inciriental to this solution, but neyertheless of considerabie oractical inportance, is the possibility if ssing preinsulated orad thereby eliminating the need tor handwrappiag of muatitijar turns. and making pussibie presinding insuiztion tests ot the :ull length at conducior.

\section{CUNDLCLOR DEVELOPHENT}

The apgraded coll cortiguration requires, in addition to the stanciard braid. a cunductor essentially of t'sice ticickness, that is 1.47 instead of $13.71 \mathrm{~mm}$. It is iatended to produce the now conductor in the ibrm of 79 strand braid with the nominal cross section of $16.5 \times 1.5 \mathrm{~mm}$ including insulation. A comparison of the oraid parameters is jiven in Table 1.

the develooment st :hick braid has been undertaken in collaboration with industry (ti2Co, lurra Hill, iew Jersev) and irst test jieces have jeen pruduced and

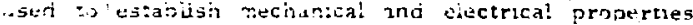

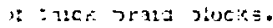

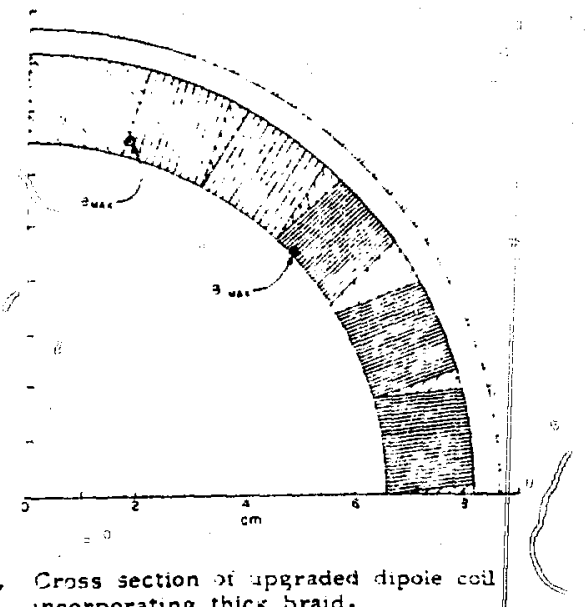

Hig. 2. Cross section ot Jpgraded
incorporating thick braid.
Table 1. Sraid Parameters

\begin{tabular}{|c|c|c|c|}
\hline & Standard & Ihick Braid & unir \\
\hline 3rait dimensions & $15.3 \times 0.7$ & $16.3 \times 1.5$ & घ्ञात \\
\hline $\begin{array}{l}\text { :lo. Ji strands } \\
\text { lire liameter }\end{array}$ & $\begin{array}{r}97 \\
0.30\end{array}$ & $\begin{array}{r}59 \\
0.57\end{array}$ & \\
\hline Filaitene fijmezer & 0 & 17 & $\min$ \\
\hline Vo. "iizments/wire & $\equiv 0,0$ & 500 & \\
\hline $\begin{array}{l}\text { Patis atrix/sc } \\
I_{c} ! ; i=e\end{array}$ & !.5 & 1.5 & \\
\hline istaij & 55 & 200 & $\lambda$ \\
\hline $\begin{array}{c}\text { J I } 54.2 \mathrm{k} \\
\text { Trarisposition }\end{array}$ & +.5 & 12 & kA \\
\hline $\begin{array}{c}\text { length } \\
\text { Incerstrand }\end{array}$ & 30 & 40 & CII \\
\hline $\begin{array}{c}\text { resisrance } \\
\text { Elast ic modulus }\end{array}$ & 25 & $\begin{array}{r}0.3 \\
14\end{array}$ & $\begin{array}{l}\mathrm{Hu} \\
\mathrm{GPa}\end{array}$ \\
\hline
\end{tabular}

Filled with staybrite (Sn.ig) bat without high resistance heat treatment.

Parentietically it should be remarked that it is. of course, possible to increase the matrix/SC ratio someshat in order to reduce the additional cost in curred trom using nore superconductor. This would retain the winding simplifications, but may cone at the expense of the full stability gain. In the case of quadrupoles such a mocified tinick braid would certainly be acceptable.

\section{COIL DESIGN CONSILERA CIUNS}

Whereas it can be expected that tne thick braid will jead to an improved training and peak field performance. it is necessary to investigate other aspects entering the coil design, such as quench propagation. ragnetization, 6-dot effects, insulation, ends, joint: of trick thin brald. etc.

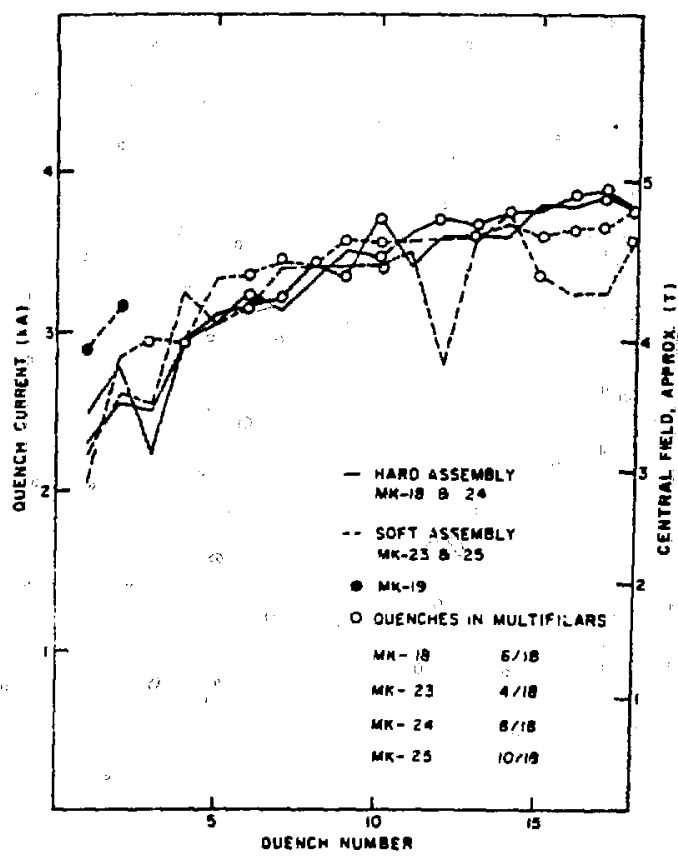

F:g. 3, Training curves of recent test jipoles. Ooen curcles represent quenches originating in Jultifular turns. 
2. Trmary concern here is azinuthal quench propagation velocity whisz, to a large extent, determines raznet seli-orotection furing a quench. Ihe naximum :umeraiure racisod in the coil during 3 cuench 15 reidted of the : titt integral and desends invergelv on

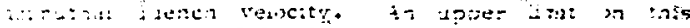
:- :raral is abou: $3.5 \mathrm{KA}$ sec in the nonotuar turns

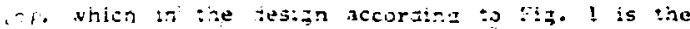

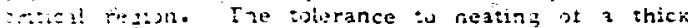

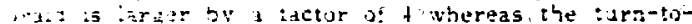

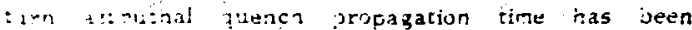

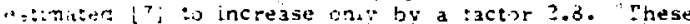
scaing argunents indicate taat the manotilar turns re7ain the eritical region in tre thick braid design $u$ $\because: 2$. ‥ Experiments on propagation through thick meta) vedges indicated that their relay is equivalent to 3 $\because 4$ monothar turns $|8|$. Results of more detailed salculations 0 ot maximum temperatures in the :roposer desizh are shown in Fig. A. suggesting that the ragnet $x$ ill be selt-protecting durin 3 quencin pro$y$ ye tad ine nomiral tonofilar turn-ij-iurn transit :-7e is iess than about 2 msec. With proper tabrication

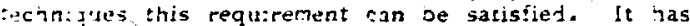
betn poservid taat azir thal quench propagation depends

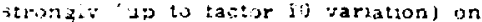

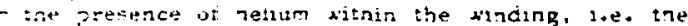
oul oorisity, ana

- fod antact petxaen turns vicr :5 helped by aressure turing the coii virding process inc assembiy.

Fidy currents indiced in the superconaucina orald whie the mazret current is being ramped can prowice sunstantia: inla cistortions and power issses. in : $x$ a power dissipation per unit lergit n: ije d:D) is isten by $\$ 12$ i

$$
F=\frac{n^{2} w^{2} i: i}{360} \frac{B^{2}}{R}
$$

Where $n, W, i$ are number of wires, width and cranspositun enfich of braid respective!y, $R$ "ine thterstrand resistance, $\because$ the total number of turns, and 3 ise ramp "ztt. incuced :ield harmonics are minimized by an exionencial ramp rate, with $B: B=5,1 \times()^{-2} \sec ^{-:}$dumng :ne 9 nin ramp ime trom 0.37 t $=[$. inder these con-

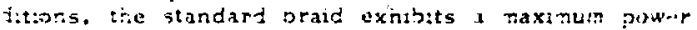

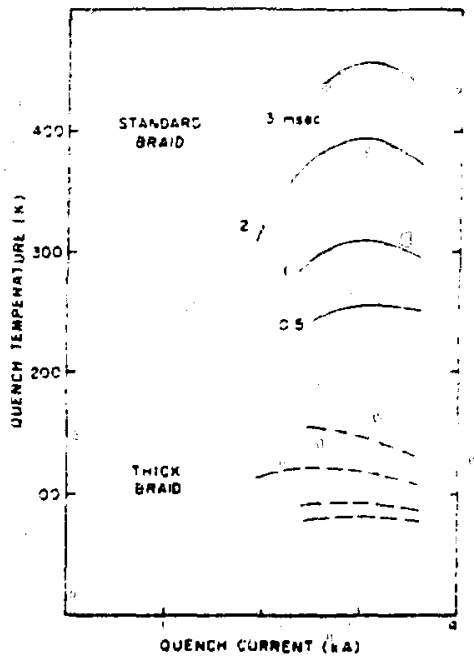

Fig. t. Calculated naximum temperature Juring f'sench which starts at the pole. Paramele is the nominal turn-to-turn transit time at 3 / 1 k. loss of 00 wim, which is unaceeptable. Heat treatmen: and sechanical craciking of braid tiller is expected to prod-lce the pared aign tesistance braid with an order of magnifude increased interstrand resistance [11]. This ireatment would also have to be applied to

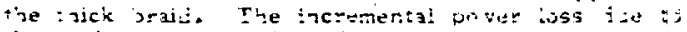
the isplication of trick braid can be estinatea to se

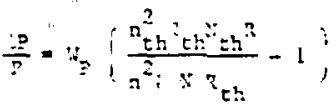

where tine index "in" refers to the shicic braid values and the feometrical weighting factor is given by

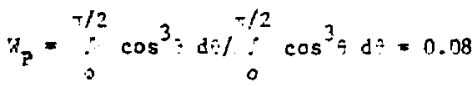

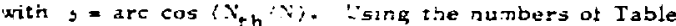
$i$ ore inds a $15 \%$ increase of tine loss. Simlar exjiessions, but with changed weighting factors apply to the anduced field harmonic cuethcients. ite cunclude that reduciag the interitrand resisidita is :at jact

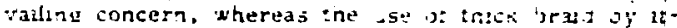
self zauses un!y minimai canges.

Induced SC rajnetzation currents in ine ilaments are the cause it siber boses and iseld changes at injection. An upper-limit estimate of tin increasc in tile iald ereticients is jiven oy

$$
\frac{\dot{b}^{3}}{b_{n}}=z_{z} \cdot \frac{c^{3} \mathrm{tin}^{2}+h^{2}+h}{d^{3} n I}-!
$$

where d. 7. I are the ilanent diameter, otal numbe: of tiarnents. and the critica! current of the brajd respectueiy. In tine nisst case, the dipoie tern, $W_{0}=0.3 j$ nealecting tio 141 muthal freld variation in the csil. One tinds that the dipole error tue to maBnetization ifcreases by dess (presumably by nuch less) than actor 3, which would seatr acceptable. Tote that ragnetization eftects couid be reduced by going to more filameats st smaller duameter.

The دpgraded c.24 : inilguration is substututional tor : Te standard coli in. tow changes in tabrication

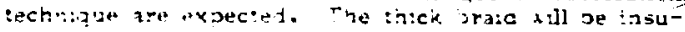

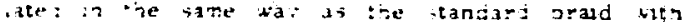

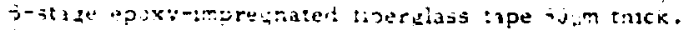

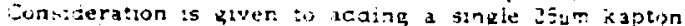
arom if better insulation is judged necessary. The necessary crorlap ont between thick and standaro arai wit be :xated at one end, and rade, by routine practice. l'ae riginer stittiess of the thick brait regutres additinal tooling to targ the ends, but no spr:ous yomplitation is expectea.

\section{TEST HALIETS}

in order is verif: ine increased itability argu-

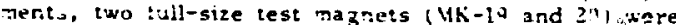
bult in wicn the iner: spacers were reoluced bv superconducting turn. SC spacers were used in earLer sinort magnets $\mid: 21$ and nore recentiy in $x_{3} \$ n$ magnets $\mid 131$ to increase the current stability of the turns near the pole. The vinding/fscheme for the iest gaxnets is snown in Fig. : I with VK-19 being insigniticantly different) and the important parameters are isted in Table 2. Botin magnets were soft assembled with it $1 K-20$ directs comparable to $\mathrm{KK}-23$ and 35 . WK-19 in contrast, was assembied iike $Y K-5$ (the best performing dipole) with stress relieved fiberglass bands. masking tape between coil and bands, and the bore tube supporting the coil. UK-19 was wound with natural ends, MK-20 wich end soacers. 


\begin{tabular}{|c|c|c|c|}
\hline & पर -14 & 1\%-20 & init \\
\hline 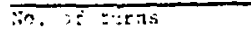 & 192 & $: 32$ & \\
\hline Trungter runction & $\therefore+23$ & $\therefore+15$ & Tiret \\
\hline ?ai? in ix? & $-\quad=4$ & $-\quad: 5$ & $10-6=n-2$ \\
\hline$\because$ & $-\quad \therefore:$ & 5.2 & $1 i-i \cdot \ldots$ \\
\hline$\because$ & $-\quad 29$ & - +4 & $1,0^{-3}=\mathrm{m}^{-5}$ \\
\hline$\dot{2}$ & $-\ldots$ & 1.22 & $12-9=3-8$ \\
\hline Landiat: $n$ ide & +5.7 & $+i .3$ & דו \\
\hline${ }_{r} ; ; \quad \therefore+2 s$ & $\rightarrow .-j \dot{j}-.3 j$ & $\therefore: 2,24.55$ & $x A$ \\
\hline$\because \because \cdots 4: 2=4$ & $\therefore$ & $? 3$ & 921 \\
\hline 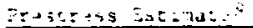 & $\Rightarrow$ & $\vdots$ & $1 p_{3}$ \\
\hline
\end{tabular}

The particliar arrangement wh superconducting :rert turns to subject tn substantial eddy current

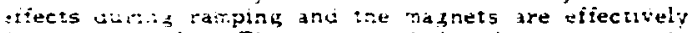
ic raxnets ti: $\because$. The maximum induced current 15 , in steady state wiping, estinater to be

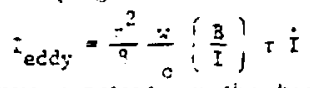

wih : the time cunstant, w the braid widh and 31 ise transier flactisr. The observed tame constant is in the jrder is ine thour resulting in bo A thduced current in tho zrate at the ramp rate of $0.01 \mathrm{~A}$ isec. The induced cirrents are additive in the transport surrent and the critcici current is easily exceeded dume; pamping. isterchanging active and spacer turns No'd have resulted in a iubtraction of the eddy cur$\because n t$ and a substantial improvement of perfurmance. Ine $\because$ he sungtant depends fuadrat:cally on the spacer turn ingta; cutting the spacer iength woud practicaliv ininate the eddy current eltects.

The effectiveness of the superconducting turns in itppressing traning quenches depends on the time reiuired to skitch the cusrent locally from the active intu the sujerconductire spacer turn (the current d:t iusivity is abiut $10^{3} \mathrm{~J}^{2} \mathrm{sec}$ ). it has been estimated that a minum propagating zone can be bypassed within i tew milseconds, which nay well se narginal at top toid. Ht lower ileids quencn recovery has been oserved.

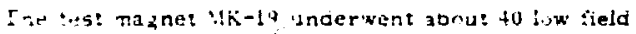

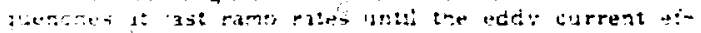

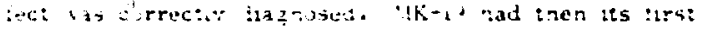

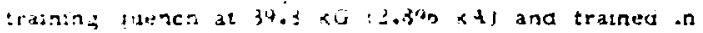

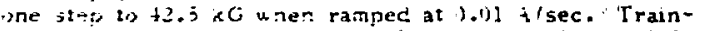
ng $x$ as stopped due to zagne: damage taused by a failure w: the guench protectson curcuit: Testing at WK-20 is torticnatis.

4 nomind ctive sirulation coli, $30 \mathrm{~cm}$ lonz. was lijund wits : ick bratd in proer to test training behaJur lac aitenca Gelocities. Vis sraming quenches were soserver at $\$ . j$ I up $t$. i. $A$. :B!

\section{Covetislor}

it is, in nur opinion, justified to discount the edidy current quenches sbserved on $11 \mathrm{k}-19$. Undier this assumption. its periormance would seem to be superior to all ther standard dipoies tested recently (Fig. 3). However, it is not possible, without further work, to attribute it to the presence of superconducting spacer turns rather than some ither aspects of the magnets, such as the particular asembly lechnique appliec to $M K-10$. The results are in anv case sufficiently encouraging to pursue the thicic braid solution with vigor.

Thiek braid has been delivered by indugtry to ?j this laboratory in quantities aciequate for construcTipn $2 \mathrm{f}$ dipole and several quadrupoles. In view of its treater simplicity, the construction $x^{-}$a fill

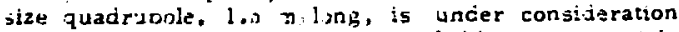
(Fiz. 3). Tir zrmary zurbose of this test maznet is

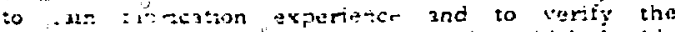

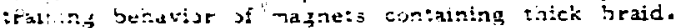
$\therefore$. : expected that inis first step will leat in the cons:ructuon of :ull-size ipole ragnets.

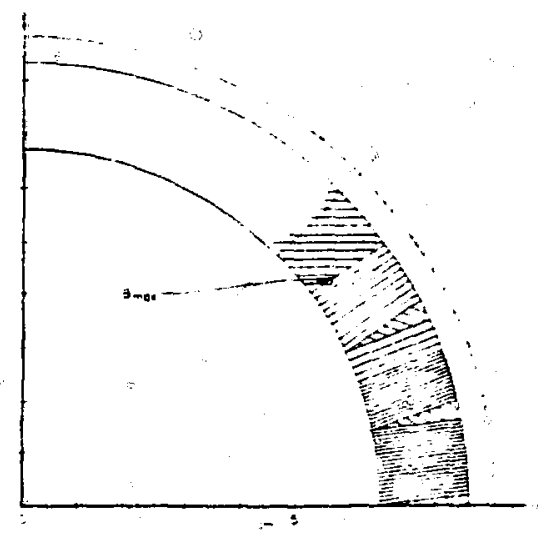

Fig. 5. Cross sectipn of thick brad quadrupole.

\section{ACXTUWLEDGMENTS}

The authors sould lske to thank the Magnet Test Facility under Dr. R. Engelmann ior testing the magnet. Illuminatine discussions with Drs. ' $v .3$. Sampson and S.L. IVip $f$ and nelpful contrbutions by $\mathrm{Dr}_{\text {. }} A$. Stevens are gratefully acknowledged.

\section{REFERENCES}

(1) H. Hainn. IEEE Trans. MAG-i7, 702 (1981).

(2) E.J. Bieser, "Cinstruceson or Supereonducting Sagnets $3 t$ B poskinaven. Vitional Laborator" "these procercinzs.

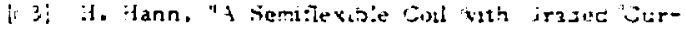
ren: Jensity ior li i i ELLE "1agrets', to be pubs lished in Proc. Sucerconducting llagnet :Jork shop. Srookhaven (13\%0\}

I th P.F. Dah] 3nd H. Harn, IEEE Trans. HAG-17, 168 (1981).

(j) S.L. Wipi. 'Stabilaty and Degradation of Superconducting Gurrent-Carryane Devices", Los Alamos Scientific Report. LATI-5, inpliblished 1978).

! 1 . Carberand N.B. Sampson. IEEE Irans. UAG-17. i? (1)81).

| 7 | S.D. Jackion. "Thtory of Transverse Quench Propagation". IS $+B E L L E$ Tecantcal vote 234 (unpublished 1980).

(1) A.B. Sampson, pritate communication (198i).

(1) A.J. Stevers, private communication (1981).

Iiq1. E.D. Courant. "Eddy Currents in Superconducting Braid", 1JABELLE Technical tole 168 (unpubblished 1980).

(1I) T. Luhman. "Hetalurzicai Characterization of VbTi Braid". 1SA3ELLE Tecnnical Sore No. 274 (unpublished 1980).

[i2] W.B.Sampson. P.F. Dahl, H.U. Helnturí, G.H. Horzan. Proc. 4th Intern. Conf. Wagnet Technology. Brookhaven 1972 (NTIS Springtield, Vi) p. 32 .

1131 N.B. Sampson, S. Kiss, K.E. Rabins, t.o. Vclnturff, IEEE Trans. NAG-15, 117 (1979). 